\title{
Leadership Assessments in Business Organizations in Indonesia
}

\author{
Arief Fahmie \\ Department of Psychology \\ Islamic University of Indonesia \\ Indonesia \\ a.fahmie@uii.ac.id \\ Dwi Despiana \\ Department of Professional Psychology \\ Islamic University of Indonesia \\ Indonesia
}

\author{
Laura Monica \\ Department of Professional Psychology \\ Islamic University of Indonesia \\ Indonesia \\ Elisa Kusrini \\ Department of Industrial Engineering \\ Islamic University of Indonesia \\ Indonesia
}

\begin{abstract}
Leadership creates a social influence practice in which the leader encourages the voluntary involvement of subordinates to achieve organization goals. For instance, to manage supply chain, leadership contributes significantly in term of flexibility and innovation. In the era of VUCA (Volatility, Uncertainty, Complexity, and Ambiguity), measurements of leadership competencies using psychological tests for staff and managers are fundamental and essential for selecting leaders who recognize the complexities of the quickly changing business global milieu. This article aims to describe three case studies of psychological test usages in selection, promotion, and potential reviews at an automotive industry in Semarang and a middle-size restaurant, Yogyakarta, Indonesia. The weaknesses and strengths of psychological assessments are explained to improve quality of organizational behaviors at workplaces and to recommend the further developments of managing human resource in business organizations.
\end{abstract}

Keywords-leadership; psychological tests, human resource management

\section{INTRODUCTION}

Developments and changes influence current business situation in various ways. VUCA (Volatility, Uncertainty, Complexity, and ambiguity) is one of the present issues in the industry. Companies continue to develop human resources, e.g. leadership because VUCA and leadership are closely connected. VUCA as an external demand forces internal conditions of companies to develop their capacities. At the corporate scope, leadership is one of the important factors to deal with external dynamic as leadership and employees' individual creativity affect innovation conditioned by a creative organizational climate [1].

Furthermore, leadership plays a role in the control of human resources and supply chain management in the company [2]. Organizations need leaders who can adapt quickly and precisely, able to think independently and able to lead with confidence using their capabilities [3, 4].
Considering VUCA issue as a framework for redesigning leadership development leads HR and talent management professionals to identify and encourage leaders their organizations needs now and in the future. For this reason, leadership education is essential for organizations to be able to deal with VUCA and other globalization environment [4]. This is in line with the research that reported leaders must have the ability to promote creativity and innovation, encourage subordinates to challenge their own value systems and improve their individual performance in order to improve organizational performance [6].

In more detail, leadership style has relationships with work environment. rResearch describes that the five leadership styles (participatory style, influence-influence, achievement orientation, directive and supportive) have a significant positive impact on job satisfaction, commitment, and employee performance. Leaders are able to influence the perception of subordinates and able to motivate subordinates to work in accordance with the goals set, clarity of duties, job satisfaction and effective implementation [7]. Another research [8, 9] also states that employees who have a transformation-style leader tend to increase their work performance. Leaders who have a transformational leadership style are able to inspire their subordinates to work harder and to produce creativity.

Each position in organization, including a manager or supervisor even staff, certainly has several criteria. These criteria then lead to required competencies individuals must meet. Competency is the ability to carry out a work based on the knowledge, skills and work attitude demanded by the work [10]. In other words, competency will bring the individual to be able to complete every job demands that fulfill organizational standards.

In business organizations, psychological measurement tools contribute to determining level of individuals' competencies as well as to predict behavior in the future. Use 
of psychological testing equipment has five classifications, namely, intelligence tests, talents, performance, interests and personality. Psychological testing is a tool that has objective standards to compare psychological states or individual behavior [11].

In human resource management, fulfilling the job requirement is very important. Qualified leaders also have an important role in organizational effectiveness. Organizations expect their leaders work in accordance with the expectations of the company and able to convey the value desired by the company to each of subordinates. Regarding this, psychological assessment has ability to describe competencies of leadership by using various tests such as BAUM, DAP, and Wartegg. The interpretation of the personality test tools can explain how the individual's leadership potential described on result of psychological assessment, including job related relationships and predictions of performance in the future. Next chapter are some case studies that explain psychological tests usage to assess leadership competencies in selection, promotion and potential review in various companies.

\section{CASE STUDY}

\section{A. Case 1: Selection}

$\mathrm{X}$ is one of the companies that serve sales and service of a Japanese branded-car. It has several dealers as a facility serving the needs of the customer. Each dealer consists of three main divisions: Administrative, Sales and Aftersales. At the appointed time, $X$ plans to open a new branch office to meet customer needs in a region. This makes the Human Resource Department investigated existed job positions in the branch offices and find potential candidates to fulfill the vacant positions. For example, one of vacant positions is the Administration Management Trainee (AMT), the position for future Administration Head who is responsible in all domestic general affairs of a branch office.

Areas of competences required for AMT are analytical thinking, achievement orientation, work styles, leadership, planning and organizing, business sense and willingness to learn at level three of five, namely acceptable level. The meaning of leadership is ability to direct and guide, listen to opinions, and provide an effective solution and seeks to develop subordinates such as coaching, counseling, and monitoring. This capability is indispensable since AMT is a position for future Administration Head who has responsibility in managing several subordinates.

Psychological testing and interviews were the methods for the selection. The duration of group test was two hours and it included TIKI-T, Kreaplin, EPSS, Wartegg, DAP, and BAUM. In more detail, to assess leadership capability, we used EPPS, Wartegg, DAP, BAUM, and individual interviews. The method of interview was Behavioral Event Interview (BEI) to reveal interviewee's past experiences in problem solving to describe the ability in dealing with problems in the future, and it took place one hour for each applicant.

One of the applicants was Subject 1. She is 24 years old and an accounting graduate from a reputable university in
Indonesia. She also has work experience in a financial institution in Central Java. The result of psychological assessment concludes that she has the requirements of AMT and she joined the next step of selection. Specifically, on measurement of leadership competency, her level is above the requirement. She has a great potential to become an effective leader in the future. The interview results revealed that the subject had the ability to encourage and ensure that his subordinates working according to the guidance. This is consistent with the definition of leadership.

\section{B. Case 2: Promotion}

The second case is an internal promotion of employee to fill the higher position, from technician to supervisor, in the new branch office. In this case, supervisor means a team leader of one or two groups consisting of several technicians. The psychological assessments aim to determine the objective recommendation, the strengths and weaknesses of candidates, and the appropriate development programs. Related to the jobs of supervisor, leadership competence is very important. The jobholders are responsible for leading some technicians so that their work performances achieve the standards set by the company and minimize complaints from customers. Assessment leadership consisted of several aspects: ability of controlling, organizing and coaching, quality control, directing and guiding subordinates.

Similar to the selection process in Case 1, the company conducted classical tests for selected technicians recommended by the head of the Workshop Department. One of test participants was Subject 2, 23 years old. He has been working as a technician in the company for five years. We chose the psychological tests measure competencies needed for supervisor jobs, namely analytical skill, problem solving, work styles, organizing, controlling, customer orientation, communication, teamwork and coaching. To measure cognitive ability, we used CFIT, $\operatorname{TKD}(3,5,6,9)$ and to measure personality, we utilized Kreaplin, EPPS, BAUM and DAP. Interviews with the BEI method was our method to disclose his abilities and compatibility with the position of supervisor. After we analyzed and integrated data from psychological assessment, we matched the data to the competencies required as a supervisor. The result showed that the candidate was qualified as a supervisor.

\section{Case 3: Potential Review}

The last case study is potential review for Subject 3, a 23year-old man. He has been working in the branch restaurant in Yogyakarta for four years as Assistant Head Food \& Beverage Service. The position requires main competency in delivering the best service to customers. An Assistant Head Food \& Beverage Service should also be able to control his subordinates in order to maintain the best quality service to every customer who comes to the restaurant. This is important in order to minimize complaints and can increase number of costumers. The employer requested this potential review as one of the performance evaluation so that the purpose of the review is to provide additional data and recommendation to make decision in promotion. 
Assistant Head Food \& Beverage Service must have various competences: intelligence, comprehension, logical thinking, emotional stability, initiative, teamwork, communication, leadership, achievement motivation, decisionmaking, problem solving, speed of work, precise work, endurance and systematic work. The required levels, three or four, namely grey areas of each competency. One of the competencies at level four is leadership. Leadership is the ability to influence, manage and direct others, especially subordinates. The assessment methods include IST, Kreaplin, Wartegg, DAP, BAUM, Papikostik and DISC. We also used a behavioral event interview conducted in the next day. The assessment results offer his psychological profile and degree of compatibility with the job requirements. It concludes that Subject 3 has adequate capabilities to perform his job as Assistant Head Food \& Beverage Service.

\section{DISCUSSION}

From the case studies, it is clear that the psychological testing is one famous and frequently application of psychology at school, business organization and government. In various organizations, it is a powerful tool to explore psychological profile including personality, cognitive ability, and work style. A study found that only leader having particular competencies, values, attitudes, abilities and proficient characteristics is able to overcome managerial challenges in VUCA situation [3]. In the selection process that is mentioned the case study, the psychological description of a potential candidate is a comprehensive picture, both strengths and weaknesses, making it easier to choose the most appropriate person for the required position. For this purpose, a valid and standardized psychological testing tool is required. The tests provided psychological information related to the potential and characteristics of applicants appropriately and even it is able to predict a person's ability.

Based on the case studies, the purpose of predictive ability of psychological assessment of leadership is to increase impact of recruitment and selection to performance. A study with the staff of General Secretariat of Department of Energy and Mineral Resources shows recruitment affects selection process significantly and selection process influences employee performance. Nevertheless, recruitment is indirectly affected the employee performance by selection process [12]. From the case study 2, the assessment leads to design coaching as the psychological intervention. The intervention design contains theoretical leadership skill and its practices. His supervisor is the person who is responsible in delivering the program he is currently one of the evaluators of his work and has sufficient experience to guide him. He should improve the organizing skill. It is a competence related to the ability to manage or organize resources (human, facilities, etc.) in a coherent, systematic, efficient and effective ways. This competency also influences capability in organizing information and documents and managing activities to achieve the organizational targets. In addition, from the case study 3 , we suggest Subject 3 needs to develop leadership competency, especially the ability to direct and guide his subordinates at workplace. Based on the psychological data, then we designed a development program, a leadership-coaching module. It contains various tasks to improve his leadership skills. This process needs direct supervision from the employer and the result of this coaching is valuable for performance evaluation. Therefore, from the case studies, psychological assessment is important to predict performance, especially leadership, as well as the intervention to improve it.

Furthermore, a continuing increase of new psychological tests, few of which suggest any real development over the ones we have now. Increasing use of computers and the web, especially in the recruitment and sifting stages, is one of the examples. Perhaps also a beginning awareness that computerized sifting needs to demonstrate that it works. For example, virtual environments (VEs) have attracted many curiosities and have provided evidence in clinical psychology, particularly in the treatment of phobias. Nevertheless, new notion of VR application in psychology occurs. Scholars consider and explore VEs as a very sophisticated system of adaptive testing. A VR based assessment tool, BIVRS (Body Image Virtual Reality Scale) is an assessment apparatus designed to measure affective and cognitive components of body image [13].

Other development of leadership assessment is implementation of Analytical Hierarchy Process (AHP). It is an application of Decision Support System (DSS) model in employee selection. Observation and interview were the data collection method. Then, the recruitment and selection team analyzed the data to identify the pattern from method used and added with the theoretical perspective. To optimize result in decision-making, the team used Microsoft Excel and Expert Choice Software [14].

A summary of trends and more radical new possibilities describe important notions to consider [15]. First, there is a tendency to change areas of competencies and to improve selection methods. rather than individuals. In addition, grade inflation in school and university exams will degrade educational qualifications, and motivate more companies to use ability tests. There is also a trend to emphasis on selecting for soft competencies other than hard competencies, such technical skill. This is related VUCA situation because employees need to be able to cope with stress, such as aggressive or violent customers. Assessment center method also are more common for various positions, despite of leadership. The method contains multiple evaluation techniques, including several job-related simulations, interviews and psychological tests. Job simulations used in assessment centers are, for instance, in-basket exercises, group discussions, simulations of interviews with artificial subordinates or clients. Secondly, radical new possibilities include enhanced biodata systems, health and physical fitness, and DNA. In developed countries, a wealth information system exists through computerized credit systems. The system is able to record economic behaviors leisure interests. It could possibly to assess people from what they choose to spend money and where they go for vacations. Moreover, if we assume fit people work better, then health information is resource to predict behaviors at work place. Such information are in medical files, however employers have no access to the files. In addition, in the future it is possible to measure 
psychological ability from analyzing of sliver of skin or drop of saliva.

\section{CONCLUSION}

Selecting and using effective assessment methods enhance quality of leadership and productivity of employees. Unfortunately, some may have misconceptions about psychological assessments and the types of assessments that have proven to be most effective. This, coupled with the fact that the area of selection testing is inherently technical and may be difficult to understand, has led to an underutilization of formal assessments in organizations. By providing a basic understanding of key criteria for evaluating assessment methods and resources for accessing assessment-related information and expertise, this article has taken a positive step to introduce effective assessment methods in organizations.

In organizational settings, human resources are strategic asset. Therefore, companies need to pay attention to the suitability between competencies in a job position and the ability of the individuals. Companies then have to develop individuals within the organization, for example, competencies of leadership, based on psychological assessment. However, companies should consider disadvantages and advantages of assessment method, including new possibilities of psychological measurements.

\section{References}

[1] Moussa, N. B. E. N, "The role of leadership, individual creativity and organizational climate in the development of innovative capability of Tunisian companies", International Review of Management and Business Research. Vol. 3 Issue.4. pp. 1828-1835. 2014.

[2] Kusrini, E, "Research in supply chain management: issue and area development", 2014.

[3] Shulka, T., Pattanaik, D., \& Maity, R, "Role of talent manager in VUCA environment. Journal of Exclusive Management Science, 4 (8), 1-9. 2015.

[4] Raišienè, A. G, "Leadership and managerial competences in a contemporary organization from the standpoint", 7(3), 179-194. 2014.

[5] Carvan, M. T, "Leadership education for the volatile, uncertain, complex and ambiguous now: a challenge to the field. Journal of Leadership Education", 4 (1), 3-10. 2015.

[6] Raharjo, S. T., \& Nafisah, D, "Analisis pengaruh gaya kepemimpinan terhadap kepuasan kerja, komitmen organisasi (Studi empiris pada Departemen Agama Kabupaten Kendal dan Departemen Agama Kota Semarang)", 3, 69-81. 2006.

[7] Hurduzeu, R. E, "The impact of leadership on organizational performance. SEA: Practical Application of Science". 3(1). 2015.

[8] Yıldız, M. L, "Organizational climate as a moderator of the relationship between transformational leadership and creativity," $I I(1), 76-87.2014$.

[9] Moussa, N. B. E. N, "The role of leadership, individual creativity and organizational climate in the development of innovative capability of Tunisian companies", 1828-1835. 2014.

[10] Wibowo, "Manajemen Kinerja". Jakarta: PT. Raja Grafindo Persada. 2007.

[11] Anastasi, A. \& Urbina, S, “Tes psikologi”, Jakarta: Indeks. 2006.

[12] Yullyanti, E, "Analisis proses rekrutmen dan seleksi pada kinerja pegawai", 16(1996), 131-139. 2009.

[13] Riva, G, "Virtual Reality as Assessment Tool in Psychology". 1998.

[14] Melia, Y, “DSS using AHP in Selection of Lecturer", 52, 35-44. 2013.

[15] Cook, M, \& Cripps, B. "Psychological assessment in the workplace a manager's guide", 1998. 